The Search for the Codex Cardona 



\section{THE SEARCH FOR THE}

\section{Codex Cardona}

ON THE TRAIL OF A SIXTEENTHCENTURY MEXICAN TREASURE

\section{Arnold J. Bauer}


() 2009 Duke University Press

All rights reserved

Printed in the

United States of America

on acid-free paper $@$

Designed by Jennifer Hill

Typeset in Quadraat by

Tseng Information Systems, Inc.

Library of Congress Cataloging-in-Publication Data appear on the last printed page of this book. 
For

David and Elaine

and

"Alex" 
